\title{
Nutrients and Risk of Colon Cancer
}

\author{
Jinfu Hu ${ }^{1, *}$, Carlo La Vecchia ${ }^{2,3}$, Eva Negri ${ }^{2}$ and Les Mery ${ }^{1}$
}

1 Evidence and Risk Assessment Division, Centre for Chronic Disease Prevention and Control, Public Health Agency of Canada, 785 Carling Avenue, AL: 6807B, Ottawa, Ontario K1A 0K9 Canada; E-Mail: Les.mery@phac-aspc.gc.ca (L.M.)

2 Istituto di Ricerche Farmacologiche "Mario Negri," Via La Masa, 19-20156 Milan, Italy; E-Mail: lavecchia@marionegri.it (L.V.C.); evanegri@marionegri.it (E.N.)

3 Istituto di Statistica Medica e Biometria, Università degli Studi di Milano, Via Venezian, 1, 20133 Milan, Italy

* Author to whom correspondence should be addressed; E-Mail: Jinfu.hu@ @phac-aspc.gc.ca; Tel.: +1-613-957-1070; Fax: +1-613-941-2633.

Received: 2 December 2009; in revised form: 19 January 2010 / Accepted: 3 February 2010 / Published: 10 February 2010

\begin{abstract}
Dietary fats are thought to be important in the etiology of colon cancer. However, the evidence linking them is inconclusive. Studies on dietary protein, cholesterol and carbohydrate and the risk of colon cancer are also inconsistent. This study examined the association between dietary intake of protein, fats, cholesterol and carbohydrates, and the risk of colon cancer. Mailed questionnaires were completed by 1731 individuals with histologically confirmed cases of colon cancer and 3097 population controls between 1994 and 1997 in seven Canadian provinces. Measurements included socio-economic status, lifestyle habits and diet. A 69-item food frequency questionnaire was used to provide data on eating habits from two years before the study. Odds ratios (OR) and 95\% confidence intervals (CI) were computed using unconditional logistic regression. The nutrients were categorized by quartiles based on the distributions among the controls. Intake of polyunsaturated fat, trans-fat and cholesterol were significantly associated with the risk of colon cancer; the ORs for the highest quartiles were 1.36 (95\% CI, 1.02-1.80), 1.37 (95\% CI, 1.10-1.71) and 1.42 (95\% CI, 1.10-1.84), respectively. The association was stronger with proximal colon cancer (PCC). An increased risk was also observed with increasing intake of sucrose for both proximal and distal colon cancers; the ORs for the highest quartiles were 1.67 (95\% CI, 1.22-2.29) for PCC and 1.58 (95\% CI, 1.18-2.10) for distal colon cancer (DCC). An elevated risk of PCC was also found with increased lactose intake.
\end{abstract}


Our findings provide evidence that a diet low in fat and sucrose could reduce the risk of various colon cancers.

Keywords: unconditional logistic regression; odds ratio; protein; fat; cholesterol; carbohydrate

Abbreviations: $\mathrm{BMI}=$ body mass index; $\mathrm{OR}=$ odds ratio; $\mathrm{CI}=$ confidence interval; $\mathrm{DCC}=$ distal colon cancer; $\mathrm{PCC}=$ proximal colon cancer; FFQ = food frequency questionnaire; IGF-I = insulin-like growth factor-I; JPHC = Japan Public Health-Center cohort study; NECSS = National Enhanced Cancer Surveillance System.

\section{Introduction}

Colorectal cancer ranks the third highest in cancer incidence and fourth in cancer mortality in both sexes combined worldwide. In developed countries, it is the leading site of cancer occurrence in nonsmokers of both sexes combined [1]. In Canada, colorectal cancer has the third highest cancer incidence in both men and women, and is the second and third leading cause of cancer-related death in men and women, respectively [2]. With reference to risk factors, considerable attention has focused on diet, and, in particular, overweight and obesity, red meat, processed meat, selected types of fat and alcohol drinking [3-6]. These factors have been related to increased risk, whereas physical activities have been suggested to reduce the risk of colon cancer. However, the evidence regarding intake of various type of fat and sugar is inconclusive [7].

An ecologic study in Japan showed increased incidence and mortality rates of colon cancer with increased intake of fat and meat [8]. A cross-sectional study from Portugal reported that intake of total fat, saturated fat, trans-fat and cholesterol was positively associated with colorectal cancer [9]. Some case-control studies reported that total fat, monounsaturated fat, polyunsaturated fat and trans-fats were positively associated with colon cancer [10,11], but this was not consistent in other studies $[12,13]$. Most cohort studies found no significant association between intake of total fat, saturated fat, monounsaturated fatty acids, polyunsaturated fat, trans-fat and the risk of colon and colorectal cancer [14-19]. An intervention trial reported that a low-fat dietary pattern did not reduce the risk of colon cancer [20]. The evidence of high consumption of fat increasing the risk of colorectal cancer is therefore inadequate [21].

Studies on other nutrients, such as cholesterol, protein and carbohydrate intake and the risk of colon cancer are also open to discussion. A few studies evaluated an association between dietary cholesterol and colon cancer. A few cohort studies found that dietary cholesterol was positively related to colon cancer [17,22], but other studies found no association between cholesterol intake and colorectal cancer $[15,16]$. Available information on protein and colon cancer is scanty. A case-control study reported that protein intake was positively associated with colon cancer in men [10], whereas other studies found no association [17,19,23]. With reference to carbohydrate intake, some studies reported positive [24] or negative [25] association with colorectal cancer or colon cancer, but most studies found no association between dietary carbohydrate and colon cancer [23,26-28]. 
To address these research gaps and inconsistencies, we therefore assessed the role of dietary intake of protein, fats, cholesterol and carbohydrates in colon cancer risk using Canadian data from a nationwide, population-based case-control study, the National Enhanced Cancer Surveillance System (NECSS) [29].

\section{Material and Methods}

The NECSS collected individual data from a population-based sample that covered 19 types of cancers and population controls in the Canadian provinces of British Columbia (BC), Alberta (AB), Saskatchewan (SASK), Manitoba (BB), Ontario (ON), Prince Edward Island (PEI), Nova Scotia (NS) and Newfoundland (NFD). The present study did not include cases and controls from Ontario. According to a request from Ontario, the provincial data on colon, rectum and bladder cancers were used by the province only. This decision was made before the project started.

\subsection{Cases}

Participating provincial cancer registries ascertained a total of 2875 histologically confirmed colon cancer cases of individuals aged 20-76 years between 1994 and 1997. Of these, 427 cases were excluded from the study because 227 patients died and 200 patients were too ill by the time of physician contact. Of 2448 questionnaires sent, 1751 were completed, the response rate being $71.5 \%$ of patients contacted. The cases with unclear topography code $(n=20)$ were excluded. Therefore, this study involved 1731 (964 male and 767 female) histologically confirmed cases of colon cancer as defined by the second edition of the International Classification of Diseases for Oncology (ICDO-2) [30]. Cases of proximal colon cancer (PCC $n=737$ ) included cancer of the caecum, the ascending colon, the hepatic flexure of the colon and the transverse colon; distal colon cancer (DCC $n=994$ ) cases included cancer of the splenic flexure of the colon, the descending colon and the sigmoid colon.

\subsection{Controls}

Frequency matching was used to select population controls to achieve overall case group with similar age and sex distributions with cases. Provincial cancer registries collected information from controls using the same protocol as for the cases at the same time. The strategies for selecting population controls varied by province, depending on data availability and accessibility. In Prince Edward Island, Nova Scotia, Manitoba, Saskatchewan and British Columbia, age group- and sexstratified random samples of population were obtained through the provincial health insurance plans. Newfoundland and Alberta used random digit dialling to obtain population samples.

Of 5119 questionnaires sent to potential controls, 81 were returned because of a wrong address; of the remainder, 3097 (1635 men and 1462 women) were completed, yielding a response rate of $61.5 \%$ of controls contacted.

\subsection{Data collection}

The cancer registries were able to identify most cases within one to three months of diagnosis based on pathology reports. After obtaining physician consent, questionnaires were mailed to cases and controls 
by the cancer registries. If the questionnaire was not completed and returned, a reminder postcard was sent out after 14 days and a second copy of the questionnaire at four weeks. After six weeks, if required, telephone follow-up was used for clarification and completeness. Information was collected on diet, height, weight, smoking history, alcohol drinking, physical activity and socio-economic status.

Data on intake of fats, protein, cholesterol, carbohydrates and energy intake were derived from a food frequency questionnaire (FFQ), which was based on two validated instruments: the short Block questionnaire [31] and the Willett questionnaire [32], with minor modifications to account for differences between the Canadian and the American diets. The FFQ was used to ascertain usual dietary intake two years before the study. The FFQ included 69 specific foods and beverages, and was grouped into eight sections: (a) breads and cereals; (b) meat, poultry, fish, eggs and cheese; (c) vegetables; (d) fruit; (e) sweets; (f) miscellaneous; (g) beverages made with water and (h) other beverages. For each food item, cases and controls were asked to describe how often (per day, per week, per month), on average, they ate the specified serving size. A nutrient database based on the 2005 version of the Canadian Nutrient File was used to estimate nutrient intake and total energy intake [33]. In addition, information on alcohol consumption (beer, wine and spirits) was also collected.

With reference to the covariates considered in the present study, we collected information on weight "about two years ago". Body mass index (BMI) was computed as weight (kg) divided by height (m) squared [33]. We defined ever-smokers as subjects who smoked at least 100 cigarettes in their entire life, and current smokers as those who were still smoking one year before the interview. Physical activity two years before the study was based on session frequency, seasons of participation and average time per session for each of 12 categories of the most common types of moderate exercise (including walking, gardening or yard work, home exercise or exercise class, golf, bowling or curling and dancing) and strenuous leisure-time physical activity (including jogging, swimming or water exercise, skiing, cycling or other strenuous exercise).

\subsection{Statistical Analysis}

Unconditional logistic regression was used to estimate odds ratios (OR) and the corresponding 95\% confidence intervals (CI). According to our previous studies using the same dataset [35,36], the following potential confounding variables were selected: sex, 10-year age group $(<49,50-59,60-69$, $70-76)$, province, education $(\leq 8,9-13, \geq 14$ years), BMI $(<25,25-29.9, \geq 30)$, alcohol drinking (never drank, $\leq 1.83,1.84-10.69, \geq 10.70$ g/day), moderate activity ( $\leq 4.63,4.64-11.83,11.84-23.96, \geq 23.97$ hours/month), strenuous activity $(\leq 0.19,0.20-3.68, \geq 3.69$ hours/month) total meat $(\leq 4.88,4.89-7.94$, $7.95-12.47, \geq 12.48$ servings/wk), red meat $(\leq 2.0,2.1-3.94,3.95-6.0, \geq 6.1$ servings/wk), processed meat $(\leq 1.41,1.42-3.41,3.42-6.94, \geq 6.95$ servings/wk), poultry $(\leq 1,1.1-3, \geq 3.1$ servings/wk), total consumption of fruit and vegetables $(\leq 14.7,14.8-22.88,22.89-31.97, \geq 31.97$ servings/wk) and total energy intake ( $\leq 10644.4,1044.5-13396.4,13396.5-16913.13, \geq 16913.14 \mathrm{kCal} / \mathrm{wk})$. P value from Chi square was used to measure the distribution between cases and controls for each variable. Tests for trend were assessed for each study variable by substituting the variable in the model in continuous form, and comparing the models without and with the variable of outcome to a chi square distribution with one degree of freedom. Each nutrient intake amount was categorized by quartiles, based on the distribution among controls (Appendix 1). All analyses were made using SAS (Version 9.1) software [37]. 


\section{Results and Discussion}

\subsection{Results}

Table 1 shows the distribution of 1731 cases of colon cancer and 3097 population controls, and the chi square values according to selected covariates. Cases were older than controls. The proportion of cases reporting overweight or obesity, alcohol drinking $(\geq 10.70 \mathrm{~g} / \mathrm{d})$ and pack-years smoking ( $>30)$ was significantly higher in the cases than in the controls. In contrast, education ( $\geq 14$ years), moderate activity ( $\geq 23.97 \mathrm{~h} / \mathrm{month}$ ) and strenuous activity $(\geq 0.20 \mathrm{~h} / \mathrm{month}$ ) was significantly higher in the controls than in cases. There was no difference between the cases and the controls regarding family income.

Table 1. Description and Chi square of selected covariates for 1731 colon cancer cases and 3097 population-based controls, NECSS, Canada, 1994-1997.

\begin{tabular}{|c|c|c|c|c|c|}
\hline & \multicolumn{2}{|c|}{ Cases } & \multicolumn{2}{|c|}{ Controls } & \multirow{2}{*}{$\begin{array}{l}\mathrm{p} \text {-value } \\
\text { for Chisq }\end{array}$} \\
\hline & No. & $\%$ & No. & $\%$ & \\
\hline \multicolumn{6}{|l|}{ Age } \\
\hline $20-49$ & 191 & 11.0 & 838 & 27.1 & $<0.0001$ \\
\hline $50-59$ & 317 & 18.3 & 605 & 19.5 & \\
\hline $60-69$ & 747 & 43.2 & 1043 & 33.7 & \\
\hline $70-76$ & 476 & 27.5 & 611 & 19.7 & \\
\hline \multicolumn{6}{|l|}{ Education (years) } \\
\hline$\leq 8$ & 319 & 18.4 & 471 & 15.2 & $<0.0001$ \\
\hline $9-13$ & 989 & 57.1 & 1689 & 54.5 & \\
\hline$\geq 14$ & 388 & 22.4 & 900 & 29.1 & \\
\hline \multicolumn{6}{|l|}{ Family income* } \\
\hline Low family income & 314 & 18.1 & 584 & 18.8 & 0.51 \\
\hline Lower-middle family income & 317 & 18.3 & 585 & 18.9 & \\
\hline Upper-middle family income & 414 & 23.9 & 779 & 25.2 & \\
\hline High family income & 255 & 14.7 & 440 & 14.2 & \\
\hline Not reported & 431 & 24.9 & 709 & 22.9 & \\
\hline \multicolumn{6}{|l|}{ Body mass index (kg/m2) } \\
\hline$<25$ & 632 & 36.5 & 1461 & 47.2 & $<0.0001$ \\
\hline $25-<30$ & 726 & 42.0 & 1176 & 38.0 & \\
\hline$\geq 30$ & 367 & 21.2 & 447 & 14.4 & \\
\hline \multicolumn{6}{|l|}{ Pack-years of smoking } \\
\hline Never smoked & 565 & 32.6 & 1123 & 36.3 & $<0.0001$ \\
\hline$\leq 10$ & 328 & 19.0 & 705 & 22.8 & \\
\hline $11-20$ & 289 & 16.7 & 470 & 15.2 & \\
\hline $21-30$ & 197 & 11.4 & 302 & 9.8 & \\
\hline$>30$ & 325 & 18.8 & 447 & 14.4 & \\
\hline \multicolumn{6}{|l|}{ Alcohol drinking (g/d) } \\
\hline Never drank & 632 & 36.5 & 1148 & 37.1 & $<0.0001$ \\
\hline$\leq 1.83$ & 221 & 12.8 & 450 & 14.5 & \\
\hline $1.84-10.69$ & 327 & 18.9 & 683 & 22.1 & \\
\hline$\geq 10.70$ & 522 & 30.2 & 752 & 24.3 & \\
\hline
\end{tabular}


Table 1. Cont.

\begin{tabular}{llllll}
\hline Moderate activity (h/month) & & & & & \\
$\leq 4.63$ & 353 & 20.5 & 676 & 21.8 & 0.04 \\
$4.64-11.83$ & 341 & 19.8 & 675 & 21.8 & \\
$11.84-23.96$ & 376 & 21.8 & 676 & 21.8 & \\
$\geq 23.97$ & 384 & 22.3 & 674 & 21.8 & \\
Not reported & 270 & 12.7 & 396 & 12.8 & \\
Strenuous activity (h/month) & & & & & \\
Never & 729 & 42.3 & 1146 & 37.0 & 0.0001 \\
$\leq 0.19$ & 103 & 6.0 & 162 & 5.2 & \\
$0.20-3.68$ & 301 & 17.5 & 644 & 20.8 & \\
$\geq 3.69$ & 299 & 17.3 & 647 & 20.9 & \\
Not reported & 292 & 16.9 & 498 & 16.1 & \\
\hline
\end{tabular}

* Household income was indicated as a categorical variable with the following values:

Low family income: $<\$ 20,000$ with $\leq 3$ people or $\$ 30,000$ with $\geq 4$ people;

Lower-middle family income: $\$ 20,000-\$ 30,000$ with $\leq 3$ people or $\$ 30,000-<\$ 50,000$ with $\geq 4$ people; Upper-middle family income: $<\$ 50,000$ with $\leq 3$ people or $\$ 50,000-\$ 100,000$ with $\geq 4$ people;

High family income: $\geq 50,000$ for up to 3 people or $\geq 100,000$ for $\geq 4$ people.

Total vegetables: tomatoes, carrots, broccoli, cabbage, cauliflower, brussel sprouts, spinach or other greens, yellow squash, green beans, corn, peas or any other vegetable; soups with vegetables, and total fruit: apples, pears, oranges, bananas, cantaloupe or other fruit, fresh or canned.

Note: Totals may vary due to missing values.

Table 2 presents the ORs (and the corresponding 95\% CIs) for intake of proteins, fats, cholesterol and carbohydrates. Intake of polyunsaturated fat, trans-fats, cholesterol and sucrose was significantly related to the risk of colon cancer; the ORs for the highest versus the lowest quartile were 1.36 (95\% CI, 1.02-1.80), 1.37 (95\% CI, 1.10-1.71), 1.42 (95\% CI, 1.10-1.84) and 1.61 (95\% CI, 1.27-2.04), respectively. No significant association between glucose intake and the risk of colon cancer was observed. Likewise, no association was observed with intake of total fat, saturated fat, monounsaturated fat, total proteins, total carbohydrate, lactose, maltose, fructose and galactose, although a significantly increased OR was observed for galactose intake in the second quartile compared with the lowest one.

Table 2. Odds ratios* and 95\% confidence intervals of fats, protein, cholesterol and carbohydrates for colon cancer, NECSS, Canada, 1994-1997.

\begin{tabular}{|c|c|c|c|c|c|}
\hline \multirow{2}{*}{$\begin{array}{c}\text { Nutrients } \\
\text { (g/wk) }\end{array}$} & \multicolumn{4}{|c|}{ Quartiles } & \multirow{2}{*}{$\begin{array}{l}\text { P-value } \\
\text { for trend }\end{array}$} \\
\hline & I (low) & II & III & IV (high) & \\
\hline Total protein & $328 / 769$ & $449 / 773$ & $449 / 775$ & $503 / 773$ & \\
\hline OR $(95 \% \mathrm{CI})$ & 1.0 (ref.) & $1.13(0.91-1.40)$ & $0.92(0.71-1.21)$ & $0.92(0.65-1.30)$ & 0.38 \\
\hline Total fat & $308 / 772$ & $440 / 769$ & $467 / 775$ & $514 / 774$ & \\
\hline OR $(95 \% \mathrm{CI})$ & 1.0 (ref.) & $1.22(0.99-1.51)$ & $1.18(0.91-1.54)$ & $1.21(0.86-1.69)$ & 0.40 \\
\hline Saturated fat & $310 / 769$ & $424 / 772$ & $466 / 774$ & $529 / 775$ & \\
\hline OR $(95 \% \mathrm{CI})$ & 1.0 (ref.) & $1.21(0.98-1.50)$ & $1.22(0.96-1.56)$ & $1.26(0.93-1.70)$ & 0.20 \\
\hline
\end{tabular}


Table 2. Cont.

\begin{tabular}{|c|c|c|c|c|c|}
\hline Monounsaturated fat & $314 / 772$ & $424 / 770$ & $478 / 774$ & $513 / 774$ & \\
\hline OR $(95 \% \mathrm{CI})$ & 1.0 (ref.) & $1.23(0.99-1.52)$ & $1.29(0.99-1.66)$ & $1.31(0.95-1.82)$ & 0.14 \\
\hline Polyunsaturated fat & $333 / 772$ & $407 / 771$ & $465 / 773$ & $524 / 774$ & \\
\hline OR $(95 \% \mathrm{CI})$ & 1.0 (ref.) & $1.15(0.93-1.41)$ & $1.22(0.97-1.55)$ & $1.36(1.02-1.80)$ & 0.04 \\
\hline Trans-fat & $318 / 773$ & $397 / 770$ & $487 / 773$ & $526 / 774$ & \\
\hline OR $(95 \% \mathrm{CI})$ & 1.0 (ref.) & $1.09(0.89-1.33)$ & $1.29(1.05-1.59)$ & $1.37(1.10-1.71)$ & 0.002 \\
\hline Cholesterol (mg/wk) & $316 / 773$ & $401 / 772$ & $489 / 772$ & $523 / 773$ & \\
\hline OR $(95 \% \mathrm{CI})$ & 1.0 (ref.) & $1.17(0.95-1.43)$ & $1.31(1.05-1.63)$ & $1.42(1.10-1.84)$ & 0.006 \\
\hline Total carbohydrates & $347 / 770$ & $417 / 772$ & $460 / 775$ & $505 / 773$ & \\
\hline OR $(95 \% \mathrm{CI})$ & 1.0 (ref.) & $1.07(0.86-1.34)$ & $1.14(0.84-1.54)$ & $1.15(0.78-1.71)$ & 0.49 \\
\hline Sucrose & $307 / 771$ & $407 / 773$ & $454 / 772$ & $561 / 774$ & \\
\hline OR $(95 \% \mathrm{CI})$ & 1.0 (ref.) & $1.18(0.97-1.44)$ & $1.30(1.05-1.61)$ & $1.61(1.27-2.04)$ & $<0.0001$ \\
\hline Lactose & $384 / 771$ & $427 / 772$ & $489 / 773$ & $729 / 774$ & \\
\hline OR $(95 \% \mathrm{CI})$ & 1.0 (ref.) & $1.09(0.90-1.31)$ & $1.09(0.90-1.32)$ & $1.01(0.83-1.24)$ & 0.93 \\
\hline Maltose & $334 / 772$ & $403 / 773$ & $490 / 770$ & $502 / 775$ & \\
\hline OR $(95 \% \mathrm{CI})$ & 1.0 (ref.) & $1.13(0.92-1.39)$ & $1.33(1.07-1.66)$ & $1.24(0.96-1.59)$ & 0.06 \\
\hline Glucose & $386 / 772$ & $400 / 774$ & $467 / 772$ & $476 / 772$ & \\
\hline OR $(95 \% \mathrm{CI})$ & 1.0 (ref.) & $1.00(0.82-1.22)$ & $1.15(0.93-1.42)$ & $1.22(0.97-1.54)$ & 0.05 \\
\hline Fructose & $387 / 772$ & $415 / 772$ & $455 / 774$ & $472 / 772$ & \\
\hline OR $(95 \% \mathrm{CI})$ & 1.0 (ref.) & $1.06(0.88-1.29)$ & $1.16(0.94-1.43)$ & $1.25(0.99-1.57)$ & 0.06 \\
\hline Galactose & $314 / 772$ & $486 / 770$ & $452 / 774$ & $477 / 774$ & \\
\hline OR $(95 \% \mathrm{CI})$ & 1.0 (ref.) & $1.39(1.15-1.69)$ & $1.21(0.99-1.48)$ & $1.20(0.97-1.50)$ & 0.41 \\
\hline
\end{tabular}

* Adjusted for 10-year age group, sex, province, education, body mass index $(<25,25-29.9, \geq 30)$, moderate activity (hours/month), strenuous activity (hours/month), alcohol drinking (g/d), pack-year smoking, total meat, red meat, processed meat, poultry, total consumption of fruit and vegetables and total energy intake.

Total meat: beef, pork, lamb, hamburger, hotdogs, bacon, sausage, smoked meat or corned beef, luncheon meats and liver.

Red meat: beef, pork or lam as a main dish, beef and pork or lam as a mixed dish, and hamburger.

Processed meat: hotdogs, lunch meat, smoked meat or corned beef, bacon and sausage.

Poultry: chicken or turkey.

Total consumption of fruit and vegetables is the same as in Table 1

Note: Totals may vary due to missing values.

Table 3 gives the ORs and 95\% CIs for intake of proteins, fats, cholesterol and carbohydrates, and the risk of PCC. Intake of polyunsaturated fat, trans-fat, cholesterol, sucrose and lactose was significantly associated with PCC: the ORs for the highest quartile were 1.47 (95\% CI $=1.00-2.16$ ), $1.48(95 \% \mathrm{CI}=1.09-2.01), 1.50(95 \% \mathrm{CI}=1.06-2.13)$ and $1.67(95 \% \mathrm{CI}=1.22-2.29)$ and $1.36(95 \%$ $\mathrm{CI}=1.04-1.79)$, respectively. An elevated risk of galactose was also seen with the second and fourth quartile, in the absence of significant trend. Intake of total fat, saturated fat, monounsaturated fat, protein, total carbohydrate, maltose, glucose and fructose was not associated with PCC. 
Table 3. Odds ratios* and $95 \%$ confidence intervals of fats, protein, cholesterol and carbohydrates for proximal colon cancer, NECSS, Canada, 1994-1997.

\begin{tabular}{|c|c|c|c|c|c|}
\hline \multirow{2}{*}{$\begin{array}{c}\text { Nutrients } \\
(\mathrm{g} / \mathrm{wk})\end{array}$} & \multicolumn{4}{|c|}{ Quartiles } & \multirow{2}{*}{$\begin{array}{l}\text { P-value } \\
\text { for trend }\end{array}$} \\
\hline & I (low) & II & III & IV (high) & \\
\hline Total protein & $138 / 769$ & $183 / 773$ & $199 / 775$ & $217 / 773$ & \\
\hline OR $(95 \% \mathrm{CI})$ & 1.0 (ref.) & $1.14(0.85-1.54)$ & $1.10(0.76-1.58)$ & $1.16(0.73-1.86)$ & 0.65 \\
\hline Total fat & $123 / 772$ & $191 / 769$ & $205 / 775$ & $218 / 774$ & \\
\hline OR $(95 \% \mathrm{CI})$ & 1.0 (ref.) & $1.35(1.00-1.81)$ & $1.36(0.95-1.96)$ & $1.37(0.87-2.18)$ & 0.26 \\
\hline Saturated fat & $134 / 769$ & $161 / 772$ & $213 / 774$ & $229 / 775$ & \\
\hline OR $(95 \% \mathrm{CI})$ & 1.0 (ref.) & $1.11(0.83-1.48)$ & $1.37(0.98-1.90)$ & $1.37(0.91-2.07)$ & 0.09 \\
\hline Monounsaturated fat & $131 / 772$ & $185 / 770$ & $205 / 774$ & $216 / 774$ & \\
\hline OR $(95 \% \mathrm{CI})$ & 1.0 (ref.) & $1.25(0.93-1.67)$ & $1.30(0.91-1.85)$ & $1.26(0.81-1.98)$ & 0.37 \\
\hline Polyunsaturated fat & $133 / 772$ & $172 / 771$ & $207 / 773$ & $225 / 774$ & \\
\hline OR $(95 \% \mathrm{CI})$ & 1.0 (ref.) & $1.20(0.91-1.60)$ & $1.38(1.00-1.90)$ & $1.47(1.00-2.16)$ & 0.05 \\
\hline Trans-fat & $122 / 773$ & $167 / 770$ & $217 / 773$ & $231 / 774$ & \\
\hline OR $(95 \% \mathrm{CI})$ & 1.0 (ref.) & $1.16(0.88-1.52)$ & $1.45(1.09-1.92)$ & $1.48(1.09-2.01)$ & 0.005 \\
\hline Cholesterol (mg/wk) & $133 / 773$ & $164 / 772$ & $215 / 772$ & $225 / 773$ & \\
\hline OR $(95 \% \mathrm{CI})$ & 1.0 (ref.) & $1.12(0.84-1.48)$ & $1.38(1.02-1.86)$ & $1.50(1.06-2.13)$ & 0.01 \\
\hline Total carbohydrates & $145 / 770$ & $178 / 772$ & $207 / 775$ & $207 / 773$ & \\
\hline OR $(95 \% \mathrm{CI})$ & 1.0 (ref.) & $1.05(0.77-1.42)$ & $1.14(0.76-1.72)$ & $1.06(0.62-1.80)$ & 0.82 \\
\hline Sucrose & $127 / 771$ & $172 / 773$ & $194 / 772$ & $244 / 774$ & \\
\hline OR $(95 \% \mathrm{CI})$ & 1.0 (ref.) & $1.19(0.90-1.56)$ & $1.32(0.99-1.77)$ & $1.67(1.22-2.29)$ & 0.001 \\
\hline Lactose & $146 / 771$ & $173 / 772$ & $212 / 773$ & $206 / 774$ & \\
\hline OR $(95 \% \mathrm{CI})$ & 1.0 (ref.) & $1.24(0.95-1.61)$ & $1.29(0.99-1.68)$ & $1.36(1.04-1.79)$ & 0.04 \\
\hline Maltose & $142 / 772$ & $175 / 773$ & $216 / 770$ & $204 / 775$ & \\
\hline OR $(95 \% \mathrm{CI})$ & 1.0 (ref.) & $1.16(0.88-1.52)$ & $1.31(0.98-1.76)$ & $1.15(0.82-1.62)$ & 0.39 \\
\hline Glucose & $163 / 772$ & $176 / 774$ & $199 / 772$ & $199 / 772$ & \\
\hline OR $(95 \% \mathrm{CI})$ & 1.0 (ref.) & $1.00(0.76-1.29)$ & $1.09(0.82-1.45)$ & $1.13(0.82-1.55)$ & 0.36 \\
\hline Fructose & $161 / 772$ & $185 / 772$ & $195 / 774$ & $196 / 772$ & \\
\hline OR $(95 \% \mathrm{CI})$ & 1.0 (ref.) & $1.09(0.84-1.42)$ & $1.13(0.84-1.50)$ & $1.16(0.85-1.59)$ & 0.40 \\
\hline Galactose & $130 / 772$ & $192 / 770$ & $196 / 774$ & $219 / 774$ & \\
\hline OR $(95 \% \mathrm{CI})$ & 1.0 (ref.) & $1.33(1.02-1.74)$ & $1.24(0.94-1.64)$ & $1.36(1.02-1.83)$ & 0.10 \\
\hline
\end{tabular}

* Adjusted for 10-year age group, sex, province, education, body mass index $(<25,25-29.9, \geq 30)$,

moderate activity (hours/month), strenuous activity (hours/month), alcohol drinking (g/d), pack-year smoking, total meat, red meat, processed meat, poultry, total consumption of fruit and vegetables and total energy intake.

Food groups are the same as in Table 1 and 2

Note: Totals may vary due to missing values.

Intake of sucrose was significantly associated with risk of DCC (Table 4); the OR for the highest quartile was 1.58 (95\% CI = 1.18-2.10). Significant trends in risk of DCC were observed for trans fat, maltose, glucose and fructose: the ORs for the highest quartile were 1.30 (95\% CI, 0.99-1.70), 1.30 (95\% CI, 0.96-1.76), 1.31 (95\% CI, 0.99-1.73) and 1.31 (95\% CI, 0.99-1.73), respectively. No association was observed with intake of total fat, each separate type of fat, except trans-fat, cholesterol, lactose and galactose. 
Table 4. Odds ratios* and $95 \%$ confidence intervals of fats, protein, cholesterol carbohydrates for distal colon cancer, NECSS, Canada, 1994-1997.

\begin{tabular}{|c|c|c|c|c|c|}
\hline \multirow{2}{*}{$\begin{array}{c}\text { Nutrients } \\
\text { (g/wk) }\end{array}$} & \multicolumn{4}{|c|}{ Quartiles } & \multirow{2}{*}{$\begin{array}{l}\text { P-value } \\
\text { for trend }\end{array}$} \\
\hline & I (low) & II & III & IV (high) & \\
\hline Total protein & $190 / 769$ & $266 / 773$ & $250 / 775$ & $286 / 773$ & \\
\hline OR $(95 \% \mathrm{CI})$ & 1.0 (ref.) & $1.09(0.84-1.40)$ & $0.79(0.57-1.10)$ & $0.74(0.49-1.13)$ & 0.06 \\
\hline Total fat & $185 / 772$ & $249 / 769$ & $262 / 775$ & $296 / 774$ & \\
\hline OR $(95 \% \mathrm{CI})$ & 1.0 (ref.) & $1.143(0.87-1.46)$ & $1.06(0.77-1.47)$ & $1.07(0.71-1.62)$ & 0.86 \\
\hline Saturated fat & $176 / 769$ & $263 / 772$ & $253 / 774$ & $300 / 775$ & \\
\hline OR $(95 \% \mathrm{CI})$ & 1.0 (ref.) & $1.29(1.00-1.67)$ & $1.12(0.83-1.51)$ & $1.16(0.80-1.69)$ & 0.72 \\
\hline Monounsaturated fat & $183 / 772$ & $239 / 770$ & $273 / 774$ & $297 / 774$ & \\
\hline OR $(95 \% \mathrm{CI})$ & 1.0 (ref.) & $1.20(0.92-1.55)$ & $1.26(0.92-1.73)$ & $1.32(0.89-1.96)$ & 0.19 \\
\hline Polyunsaturated fat & $200 / 772$ & $235 / 771$ & $258 / 773$ & $299 / 774$ & \\
\hline OR $(95 \% \mathrm{CI})$ & 1.0 (ref.) & $1.12(0.87-1.44)$ & $1.11(0.83-1.47)$ & $1.26(0.90-1.78)$ & 0.23 \\
\hline Trans-fat & $196 / 773$ & $230 / 770$ & $270 / 773$ & $295 / 774$ & \\
\hline OR $(95 \% \mathrm{CI})$ & 1.0 (ref.) & $1.06(0.83-1.35)$ & $1.21(0.94-1.55)$ & $1.30(0.99-1.70)$ & 0.03 \\
\hline Cholesterol (mg/wk) & $183 / 773$ & $237 / 772$ & $274 / 772$ & $298 / 773$ & \\
\hline OR $(95 \% \mathrm{CI})$ & 1.0 (ref.) & $1.19(0.93-1.53)$ & $1.24(0.95-1.63)$ & $1.35(0.99-1.85)$ & 0.07 \\
\hline Total carbohydrates & $202 / 770$ & $239 / 772$ & $253 / 775$ & $298 / 773$ & \\
\hline OR $(95 \% \mathrm{CI})$ & 1.0 (ref.) & $1.10(0.84-1.45)$ & $1.12(0.77-1.61)$ & $1.23(0.76-1.97)$ & 0.44 \\
\hline Sucrose & $180 / 771$ & $235 / 773$ & $260 / 772$ & $317 / 774$ & \\
\hline OR $(95 \% \mathrm{CI})$ & 1.0 (ref.) & $1.19(0.93-1.52)$ & $1.28(0.99-1.66)$ & $1.58(1.18-2.10)$ & 0.002 \\
\hline Lactose & $238 / 771$ & $254 / 772$ & $277 / 773$ & $223 / 774$ & \\
\hline OR $(95 \% \mathrm{CI})$ & 1.0 (ref.) & $1.01(0.81-1.27)$ & $0.98(0.78-1.24)$ & $0.81(0.63-1.03)$ & 0.09 \\
\hline Maltose & $192 / 772$ & $228 / 773$ & $274 / 770$ & $298 / 775$ & \\
\hline OR $(95 \% \mathrm{CI})$ & 1.0 (ref.) & $1.10(0.86-1.41)$ & $1.33(1.02-1.73)$ & $1.30(0.96-1.76)$ & 0.05 \\
\hline Glucose & $223 / 772$ & $224 / 774$ & $268 / 772$ & $277 / 772$ & \\
\hline OR $(95 \% \mathrm{CI})$ & 1.0 (ref.) & $0.97(0.76-1.23)$ & $1.21(0.94-1.56)$ & $1.31(0.99-1.73)$ & 0.02 \\
\hline Fructose & $226 / 772$ & $230 / 772$ & $260 / 774$ & $276 / 772$ & \\
\hline OR $(95 \% \mathrm{CI})$ & 1.0 (ref.) & $1.03(0.81-1.30)$ & $1.20(0.93-1.54)$ & $1.31(0.99-1.73)$ & 0.03 \\
\hline Galactose & $184 / 772$ & $294 / 770$ & $256 / 774$ & $258 / 774$ & \\
\hline OR $(95 \% \mathrm{CI})$ & 1.0 (ref.) & $1.45(1.14-1.83)$ & $1.19(0.93-1.53)$ & $1.11(0.85-1.45)$ & 0.93 \\
\hline
\end{tabular}

* Adjusted for 10-year age group, sex, province, education, body mass index $(<25,25-29.9, \geq 30)$,

moderate activity (hours/month), strenuous activity (hours/month), alcohol drinking (g/d), pack-year smoking, total meat, red meat, processed meat, poultry, total consumption of fruit and vegetables and total energy intake.

Food groups are the same as in Table 1 and 2; Note: Totals may vary due to missing values.

\subsection{Discussion}

In this large, nationwide, population-based case-control study, we found that intake of polyunsaturated fat, trans-fat and cholesterol was significantly associated with PCC. An increased risk was also observed with increased intake of sucrose in both sides of colon, lactose in PCC, and glucose and fructose in DCC. No association was found between intake of total fat, saturated fat, monounsaturated fat, protein, maltose, galactose or total carbohydrates and both PCC and DCC. 
Most attention thus far has been given to dietary meat and fat intake and the risk of colorectal cancer. A substantial amount of evidence shows that red and processed meat are related to colorectal cancer [7]; the main sources of fat in this study were meat. In the same dataset, consumption of red and processed meat was positively associated with colon cancer $[35,36]$. In line with these findings, in the present study, dietary polyunsaturated fat and trans-fat were significantly related to the risk of colon cancer. Other case-control studies also reported that intake of total fat, monounsaturated fat and polyunsaturated fat was related to colon cancer [10,11], whereas this was not seen in another study [38]. The association between dietary fat (and types of fat) and the risk of colorectal cancer are inconsistent [39]. Most cohort studies [14-19] and a meta-analysis of six prospective studies [40] did not support an association between intake of total fat, saturated fat, monounsaturated fat and polyunsaturated fat and the risk of colon or colorectal cancer. However, a cohort study observed that a high intake of animal fat increased the risk of colon cancer [41]. It remains thus possible that some types of fat could be related to this cancer [42].

Studies on trans-fat and colon cancer are sparse. A case-control study showed that trans-fatty acids were related to colorectal cancer [43], but this was not supported by two cohort studies [15,16]. Another study reported that consumption of trans-fatty acids, but not the cis form, was associated with an increased risk of colon cancer, which was stronger in women with PCC [11]. Our results show that an increased intake of trans-fat was related to the risk of both PCC and DCC. Trans-fat appears to impact markers of systemic inflammation [44], and trans-fats adversely affect endothelial function [45]. Patients with inflammatory bowel disease such as ulcerative colitis and Crohn's disease are at high risk for developing colon cancer [46]. Chronic inflammation and colorectal cancer are closely linked [47]. A cohort study in Korea found that an elevated white blood cell count was associated with an increase in both mortality and incidence rates of colon cancer, and suggested that inflammation increases the risk of colon cancer [48]. An animal model showed the molecular, classical nuclear factor-kB (NF- $\kappa \mathrm{B})$ activation, links between chronic inflammation and colon tumorigenesis [49].

Inconsistent data are available on cholesterol and colon cancer. A small case-control study suggested an association between low blood cholesterol and colorectal cancer [50]. Three cohort studies found that dietary cholesterol was directly related to colon and colorectal cancer $[17,22,25]$. This finding was consistent with our results, but not with other studies [15,16,51]. The JPHC cohort study indicated that serum cholesterol levels were not related to the risk of colorectal cancer [52]. An animal study reported cholesterol acts as a co-carcinogen in the development of colorectal cancer [53].

A Japanese cohort study observed an increased risk of colon cancer with intake of animal protein in men only [54]. In contrast, an inverse association between protein intake and colorectal cancer was found in women in the US [18] and, specifically, with milk protein in Finnish men [15] and soy protein in Chinese women [55]. No association was shown in other cohort studies [17,19] and in a metaanalysis of animal protein [40], in broad agreement with our results.

A cohort study reported that dietary carbohydrate intake was inversely associated with the risk of colon cancer in women [25]. In contrast, another cohort study observed that a diet with high dietary carbohydrates was positively related to the risk of colorectal cancer in women [24]. However, several cohort studies [26-28,56-60] and meta-analyses [61,62] did not support the hypothesis that carbohydrate intake increases the risk of colon or colorectal cancer. Two cohort studies indicated that total carbohydrate intake was not related to PCC and RCC [27,28], in agreement with our findings. A 
large Korean cohort study reported that fasting serum glucose level was not related to colorectal cancer in men and women [63], as did a study in Sweden of men and women combined [64]. A case-control study reported that high intake of sucrose increased the risk of colon cancer [65], in agreement with our data. A meta-analysis suggested that subjects who develop colorectal cancer have increased prediagnostic blood levels of insulin and glucose [66]. A plausible mechanism from experimental studies in mice showed that sucrose intake might increase the risk of colon cancer by increasing circulating levels of insulin and insulin-like growth factor-I (IGF-I) [67]. A sucrose-rich diet caused mutations in the rat colon epithelium [68].

Recent evidence indicates that PCC and DCC may have distinct pathogenic mechanisms [69,70]. In the present study, we found that intake of polyunsaturated fat and trans-fat was significantly associated with PCC, but not with DCC. Another study also reported that intake of total fat, monounsaturated fat and saturated fat was associated with PCC, but not with DCC [10]. A cohort study showed that long term high-fat dairy food reduced the risk of DCC, whereas there was no association with PCC [71]. It is possible that some factors play different roles in each side of colon, since proximal and distal segments of the large intestine have different embryologic origins and biologic characteristics, and proximal and distal tumours follow broadly different molecular pathways of carcinogenesis $[70,72]$.

Several explanations could be considered from some of the inconsistent results of the relation of diet and colorectal cancer. Retrospective case-control studies on diet and colon cancer could be influenced by recall and selection bias. Some cohort studies involved small number of cases, which could not have adequate power to show significant results.

Our study is a large, population-based investigation from seven Canadian provinces, based on a widely used and validated FFQ [31]. Nevertheless, possible limitations should be mentioned, in particular, the validity of information on dietary habits two years before the study. The possibility of differential misclassification of exposure cannot be ruled out, but non-differential misclassification between cases and controls would bias the ORs toward unity in most instances [73]. Consequently, the actual risks may be stronger than observed. Cases might report their food intake differently than controls. However, the project was presented to subjects as a "Canadian study of health and the environment", thus limiting the scope for differential reporting. It has been shown that recall of FFQ data by controls is satisfactorily reproducible [74].

Selection bias and confounding are also of concern. About $15 \%$ of the cases (who were too ill or had died) were not included in this study. Family history of colon cancer increases risk of colon cancer [75,76], with a stronger association at younger age. In the present study, $11 \%$ of cases were under 50 years old. However, we did not collect information on family history of colon cancer. However, we were able to allow in the analyses for a large number of potential confounding factors, including age, province, education, body mass index, alcohol, tobacco, physical activity, meat and energy intake.

\section{Conclusions}

In the present study, we found that dietary intake of polyunsaturated fat, trans-fat and cholesterol was significantly associated with PCC. An increased risk was also observed with increasing intake of sucrose for both sides of the colon (PCC and DCC), of lactose for PCC, and of glucose and fructose 
for DCC. No association was found with intake of proteins, maltose, galactose or total carbohydrates in both PCC and DCC.

The findings of this study provide further evidence that a diet rich in several types of fat and sucrose is associated with a risk of colon cancer. This role may be different in various anatomic sibsites.

\section{Acknowledgements}

Contributed to the manuscript: The Canadian Cancer Registries Epidemiology Research Group comprises a principal investigator from each of the provincial cancer registries involved in the National Enhanced Cancer Surveillance System: Bertha Paulse, MSc, BN, Newfoundland Cancer Foundation; Ron Dewar, MA, Nova Scotia Cancer Registry; Dagny Dryer, MD, Prince Edward Island Cancer Registry; Nancy Kreiger, PhD, Cancer Care Ontario; Heather Whittaker, Manitoba Cancer Treatment and Research Foundation; Diane Robson, BA, Saskatchewan Cancer Foundation; Shirley Fincham, PhD, Alberta Cancer Board; and Nhu Le, PhD, British Columbia Cancer Agency. CLV and EN were supported by the Italian Association for Cancer Research and the Italian League against Cancer. The authors thank I. Garimoldi for assistance of preparing the manuscript.

\section{References}

1. Parkin, D.M.; Bray, F.; Ferlay, J.; Pisani, P. Global cancer statistics, 2002. CA Cancer J. Clin. 2005, 55, 74-108.

2. Canadian Cancer Society/National Cancer Institute of Canada. Canadian Cancer Statistics 2008; Canadian Cancer Society: Toronto, Canada, 2008.

3. Norat, T.; Bingham, S.; Ferrari, P.; Slimani, N.; Jenab, M.; Mazuir, M.; Overvad, K.; Olsen, A.; Tjønneland, A.; Clavel, F.; Boutron-Ruault, M.C.; Kesse, E.; Meat, fish, and colorectal cancer risk: the European prospective investigation into cancer and nutrition. J. Natl. Cancer Inst. 2005, 97, 906-916.

4. Sandhu, M.S.; White, I.R.; McPherson, K. Systematic review of the prospective cohort studies on meat consumption and colorectal cancer risk: a meta-analytical approach. Cancer Epidemiol. Biomarkers Prev. 2001, 10, 439-446.

5. Norat, T.; Lukanova, A.; Ferrari, P.; Riboli, E. Meat consumption and colorectal cancer risk: dose-response meta-analysis of epidemiological studies. Int. J. Cancer 2002, 98, 241-256.

6. Joshi, A.D.; Corral, R.; Siegmund, K.D.; Haile, R.W.; Le Marchand, L.; Martínez, M.E.; Ahnen, D.J.; Sandler, R.S.; Lance, P.; Stern, M.C. Red meat and poultry intake, polymorphisms in the nucleotide excision repair and mismatch repair pathways and colorectal cancer risk. Carcinogenesis 2009, 30, 472-479.

7. World Cancer Research Fund and American Institute for Cancer Research. Food, Nutrition, Physical Activity, and the Prevention of Cancer: a Global Perspective; American Institute for Cancer Research: Washington, DC, USA, 2007; pp. 280-288.

8. Kono, S. Secular trend of colon cancer incidence and mortality in relation to fat and meat intake in Japan. Eur. J. Cancer Prev. 2004, 13, 127-132. 
9. Ravasco, P.; Monteiro-Grillo, I.; Marqués Vidal, P.; Camilo, M.E. Nutritional risks and colorectal cancer in a Portuguese population. Nutr. Hosp. 2005, 20, 165-172.

10. West, D.W.; Slattery, M.L.; Robison, L.M.; Schuman, K.L.; Ford, H.; Mahoney, A.W.; Lyon, J.L.; Sorensen, A.W. Dietary intake and colon cancer: sex- and anatomic site-specific associations. Am. J. Epidemiol. 1989, 130, 883-894.

11. Slattery, M.L.; Benson, J.; Ma, K.N.; Schaffer, D.; Potter, J.D. Trans-fatty acids and colon cancer. Nutr. Cancer 2001, 39, 170-175.

12. Franceschi, S.; La Vecchia, C.; Russo, A.; Favero, A.; Negri, E.; Conti, E.; Montella, M.; Filiberti, R.; Amadori, D.; Decarli, A. Macronutrient intake and risk of colorectal cancer in Italy. Int. J. Cancer. 1998, 76, 321-324.

13. Slattery, M.L.; Potter, J.D.; Duncan, D.M.; Berry, T.D. Dietary fats and colon cancer: assessment of risk associated with specific fatty acids. Int. J. Cancer. 1997, 73, 670-677.

14. Terry, P.; Bergkvist, L.; Holmberg, L.; Wolk, A. No association between fat and fatty acids intake and risk of colorectal cancer. Cancer Epidemiol. Biomarkers Prev. 2001, 10, 913-914.

15. Pietinen, P.; Malila, N.; Virtanen, M.; Hartman, T.J.; Tangrea, J.A.; Albanes, D.; Virtamo, J. Diet and risk of colorectal cancer in a cohort of Finnish men. Cancer Causes Control 1999, 10, 387-396.

16. Lin, J.; Zhang, S.M.; Cook, N.R.; Lee, I.M.; Buring, J.E. Dietary fat and fatty acids and risk of colorectal cancer in women. Am. J. Epidemiol. 2004, 160, 1011-1022.

17. Järvinen, R.; Knekt, P.; Hakulinen, T.; Rissanen, H.; Heliövaara, M. Dietary fat, cholesterol and colorectal cancer in a prospective study. Br. J. Cancer 2001, 85, 357-361.

18. Kato, I.; Akhmedkhanov, A.; Koenig, K.; Toniolo, P.G.; Shore, R.E.; Riboli, E. Prospective study of diet and female colorectal cancer: the New York University Women's Health Study. Nutr. Cancer 1997, 28, 276-281.

19. Oba, S.; Shimizu, N.; Nagata, C.; Shimizu, H.; Kametani, M.; Takeyama, N.; Ohnuma, T.; Matsushita, S. The relationship between the consumption of meat, fat, and coffee and the risk of colon cancer: a prospective study in Japan. Cancer Lett. 2006, 244, 260-267.

20. Beresford, S.A.; Johnson, K.C.; Ritenbaugh, C.; Lasser, N.L.; Snetselaar, L.G.; Black, H.R.; Anderson, G.L.; Assaf, A.R.; Bassford, T.; Bowen, D.; et al. Low-fat dietary pattern and risk of colorectal cancer: the Women's Health Initiative Randomized Controlled Dietary Modification Trial. JAMA 2006, 295, 643-654.

21. Johnson, I.T.; Lund, E.K. Review article: nutrition, obesity and colorectal cancer. Aliment Pharmacol. Ther. 2007, 26, 161-181.

22. Lee, S.A.; Shu, X.O.; Yang, G.; Li, H.; Gao, Y.T.; Zheng, W. Animal origin foods and colorectal cancer risk: a report from the Shanghai Women's Health Study. Nutr. Cancer 2009, 61, 194-205.

23. Satia-Abouta, J.; Galanko, J.A.; Potter, J.D.; Ammerman, A.; Martin, C.F.; Sandler, R.S. Association of total energy and macronutrients with colon cancer risk in African Americans and White: results from the North Carolina colon cancer study. Am. J. Epidemiol. 2003, 158, 951-962.

24. Higginbotham, S.; Zhang, Z.F.; Lee, I.M.; Cook, N.R.; Giovannucci, E.; Buring, J.E.; Liu, S. Women's Health Study. Dietary glycemic load and risk of colorectal cancer in the Women's Health Study. J. Natl. Cancer Inst. 2004, 96, 229-233. 
25. Howarth, N.C.; Murphy, S.P.; Wilkens, L.R.; Henderson, B.E.; Kolonel, L.N. The association of glycemic load and carbohydrate intake with colorectal cancer risk in the Multiethnic Cohort Study. Am. J. Clin. Nutr. 2008, 88, 1074-1082.

26. Oh, K.; Willett, W.C.; Fuchs, C.S.; Giovannucci , E.L. Glycemic index, glycemic load, and carbohydrate intake in relation to risk of distal colorectal adenoma in women. Cancer Epidemiol. Biomarkers Prev. 2004, 13, 1192-1198.

27. Kabat, G.C.; Shikany, J.M.; Beresford, S.A.; Caan, B.; Neuhouser, M.L.; Tinker, L.F.; Rohan, T.E. Dietary carbohydrate, glycemic index, and glycemic load in relation to colorectal cancer risk in the Women's Health Initiative. Cancer Causes Control 2008, 19, 1291-1298.

28. Larsson, S.C.; Giovannucci, E.; Wolk, A. Dietary carbohydrate, glycemic index, and glycemic load in relation to risk of colorectal cancer in women. Am. J. Epidemiol. 2007, 165, 256-261.

29. Johnson, K.C.; Mao, Y.; Argo, J.; Dubois, S.; Semenciw, R.; Lava, J. and The Canadian Cancer Registries Epidemiology Reserch Group. The National Enhanced Cancer Surveillance System: a case-control approach to environmental-related cancer surveillance in Canada. Environmetrics 1998, 9, 495-504.

30. Percy, C.; Holten, V.V.; Muir, C. International Classification of Diseases for Oncology, 2nd ed.; World Health Organization: Geneva, Switzerland, 1990.

31. Block, G.; Hartman, A.M.; Naughton, D. A reduced dietary questionnaire: development and validation. Epidemiology 1990, 1, 58-64.

32. Willett, W.C. Nutritional Epidemiology, 2nd ed.; Oxford University Press: New York, NY, USA, 1998.

33. Health Canada. Canadian Nutrient File Compilation of Canadian Food Composition Data; Nutrition Research Division and Office of Information Management Technology Health Products and Food Branch, Health Canada: Ottawa, Canada, 2005.

34. World Health Organization. Obesity: Preventing and Managing the Global Epidemic; World Health Organization Technical Report Series, No. 894. Report of a WHO consultation. World Health Organization: Geneva, Switzerland, 2000.

35. Hu, J.; La Vecchia, C.; DesMeules, M.; Negri, E.; Mery, L.; Canadian Cancer Registries Epidemiology Research Group. Meat and fish consumption and cancer in Canada. Nutr. Cancer 2008, 60, 313-324.

36. Hu, J.; Morrison, H.; Mery, L.; Desmeules, M.; Macleod, M.; Canadian Cancer Registries Epidemiology Research Group. Diet and vitamin or mineral supplementation and risk of colon cancer by subsite in Canada. Eur. J. Cancer Prev. 2007, 16, 275-291.

37. SAS Institute Inc. The SAS System for Windows Release 9.01; SAS Institute: Carey, NC, USA, 2002.

38. Chiu, B.C.; Ji, B.T.; Dai, Q.; Gridley, G.; McLaughlin, J.K.; Gao, Y.T.; Fraumeni, J.F., Jr.; Chow W.H. Dietary factors and risk of colon cancer in Shanghai, China. Cancer Epidemiol. Biomarkers Prev. 2003, 12, 201-208.

39. Chepyala, P.; Aduli, F.; Olden, K.W. Primary prevention of colorectal cancer: an evidence-based approach. J. Ark. Med. Soc. 2008, 104, 290-292.

40. Alexander, D.D.; Cushing, C.A.; Lowe, K.A.; Sceurman, B.; Roberts, M.A. Meta-analysis of animal fat or animal protein intake and colorectal cancer. Am. J. Clin Nutr. 2009, 89, 1402-1409. 
41. Willet, W.C.; Stampfer, M.J.; Colditz, G.A.; Rosner, B.A.; Speizer, F.E. Relation of meat, fat, and fiber intake to the risk of colon cancer in a pprospective study among women. N. Engl. J. Med. 1990; 323, 1664-1672.

42. Giovannucci, E.; Goldin, B. The role of fat, fatty acids, and total energy intake in the etiology of human colon cancer. Am. J. Clin. Nutr. 1997, 66, 1564S-1571S.

43. Theodoratou, E.; McNeill, G.; Cetnarskyj, R.; Farrington, S.M.; Tenesa, A.; Barnetson, R.; Porteous, M.; Dunlop, M.; Campbell, H. Dietary fatty acids and colorectal cancer: a case-control study. Am J. Epidemiol. 2007, 166, 181-195.

44. Mozaffarian, D.; Pischon, T.; Hankinson, S.E.; Rifai, N.; Joshipura, K.; Willett, W.C.; Rimm, E.B. Dietary intake of trans fatty acids and systemic inflammation in women. Am. J. Clin. Nutr. 2004, 79, 606-612.

45. Lopez-Garcia, E.; Schulze, M.B.; Meigs, J.; Manson, J.E, Rifai, N.; Stampfer, M.J.; Willett, W.C.; $\mathrm{Hu}$, F.B. Consumption of trans fatty acids is related to plasma biomarkers of inflammation and endothelial dysfunction. J. Nutr. 2005, 135, 562-566.

46. Itzkowitz, S.H.; Yio, X. Inflammation and cancer IV. Colorectal cancer in inflammatory bowel disease: the role of inflammation. Am. J. Physiol. Gastrointest. Liver Physiol. 2004, 287, G7-17.

47. Chapkin, R.S.; Davidson, L.A.; Ly, L.; Weeks, B.R.; Lupton, J.R.; McMurray, D.N. Immunomodulatory effects of (n-3) fatty acids: putative link to inflammation and colon cancer. $J$. Nutr. 2007, 137, 200S-204S.

48. Lee, Y.J.; Lee, H.R.; Nam, C.M.; Hwang, U.K.; Jee, S.H. White blood cell count and the risk of colon cancer. Yonsei Med. J. 2006, 47, 646-656.

49. Karin, M.; Greten, F.R. NF-kappaB: linking inflammation and immunity to cancer development and progression. Nat. Rev. Immunol. 2005, 5, 749-759.

50. De Stefani, E.; Mendilaharsu, M.; Deneo-Pellegrini, H.; Ronco, A. Influence of dietary levels of fat, cholesterol, and calcium on colorectal cancer. Nutr. Cancer 1997, 29, 83-89.

51. Sandler, R.S.; Lyles, C.M.; Peipins, L.A.; McAuliffe, C.A.; Woosley, J.T.; Kupper, L.L. Diet and risk of colorectal adenomas: macronutrients, cholesterol, and fiber. J. Natl. Cancer Inst. 1993, 85, 884-891.

52. Iso, H.; Ikeda, A.; Inoue, M.; Sato, S.; Tsugane, S. Serum cholesterol levels in relation to the incidence of cancer: The JPHC study cohorts. Int. J. Cancer 2009, 125, 2679-2686.

53. Hiramatsu, Y.; Takada, H.; Yamamuram, M.; Hioki, K.; Saito, K.; Yamamoto, M. Effect of dietary cholesterol on azoxymethane-induced colon carcinogenesis in rats. Carcinogenesis 1983, 4, 553-558.

54. Nagata, C.; Shimizu, H.; Kametani M.; Takeyama, N.; Ohnuma, T.; Matsushita, S. Diet and colorectal adenoma in Japanese males and females. Dis. Colon Rectum 2001, 44, 105-111.

55. Yang, G.; Shu, X.O.; Li, H.; Chow, W.H.; Cai, H.; Zhang, X.; Gao, Y.T.; Zheng, W. Prospective cohort study of soy food intake and colorectal cancer risk in women. Am. J. Clin. Nutr. 2009, 89, 577-583.

56. McCarl, M.; Harnack, L.; Limburg, P.J.; Anderson, K.E.; Folsom, A.R. Incidence of colorectal cancer in relation to glycemic index and load in a cohort of women. Cancer Epidemiol. Biomarkers Prev. 2006, 15, 892-896. 
57. Flood, A.; Peters, U.; Jenkins, D.J.; Chatterjee, N.; Subar, A.F.; Church, T.R.; Bresalier, R.; Weissfeld, J.L.; Hayes, R.B.; Schatzkin, A.; Prostate, Lung, Colorectal, Ovarian (PLCO) Project Team. Carbohydrate, glycemic index, and glycemic load and colorectal adenomas in the Prostate, Lung, Colorectal, and Ovarian Screening Study. Am. J. Clin. Nutr. 2006, 84, 1184-1192.

58. Strayer, L.; Jacobs, D.R., Jr.; Schairer, C.; Schatzkin, A.; Flood, A. Dietary carbohydrate, glycemic index, and glycemic load and the risk of colorectal cancer in the BCDDP cohort. Cancer Causes Control 2007, 18, 853-863.

59. Weijenberg, M.P.; Mullie, P.F.; Brants, H.A.; Heinen, M.M.; Goldbohm, R.A.; van den Brandt, P.A. Dietary glycemic load, glycemic index and colorectal cancer risk: results from the Netherlands Cohort Study. Int. J. Cancer 2008, 122, 620-629.

60. George, S.M.; Mayne, S.T.; Leitzmann, M.F.; Park, Y.; Schatzkin, A.; Flood, A.; Hollenbeck, A.; Subar, A.F. Dietary glycemic index, glycemic load, and risk of cancer: a prospective cohort study. Am. J. Epidemiol. 2009, 169, 462-472.

61. Barclay, A.W.; Petocz, P.; McMillan-Price, J.; Flood, V.M.; Prvan, T.; Mitchell, P.; Brand-Miller, J.C. Glycemic index, glycemic load, and chronic disease risk - a meta-analysis of observational studies. Am. J. Clin. Nutr. 2008, 87, 627-637.

62. Mulholland, H.G.; Murray, L.J.; Cardwell, C.R.; Cantwell, M.M. Glycemic index, glycemic load, and risk of digestive tract neoplasms: a systematic review and meta-analysis. Am. J. Clin. Nutr. 2009, 89, 568-576.

63. Jee, S.H.; Ohrr, H.; Sull, J.W.; Yun, J.E.; Ji, M.; Samet, J.M. Fasting serum glucose level and cancer risk in Korean men and women. JAMA 2005, 293, 194-202.

64. Stattin, P.; Ove Björ, O.; Ferrari, P.; Lukanova, A.; Lenner, P.; Lindahl, B.; Hallmans, G.; Kaaks, R. Prospective study of hyperglycemia and cancer risk. Diabetes Care 2007, 30, 561-567.

65. De-Stefani E, Mendilaharsu M, Deneo-Pellegrini H. Sucrose as a risk factor for cancer of colon and rectum: a case-control study in Uruguay. Int. J. Cancer 1998, 75, 40-44,

66. Pisani, P. Hyper-insulinaemia and cancer, meta-analyses of epidemiological studies. Arch. Physiol. Biochem. 2008, 114, 63-70.

67. Wang, B.; Bobe, G.; LaPres, J.J.; Bourquin, L.D. High sucrose diets promote intestinal epithelial cell proliferation and tumorigenesis in APC (Min) mice by increasing insulin and IGF-I levels. Nutr. Cancer 2009, 61, 81-93.

68. Dragsted, L.O.; Daneshvar, B.; Vogel, U.; Autrup, H.N.; Wallin, H.; Risom, L.; Møller, P.; Mølck, A.M.; Hansen, M.; Poulsen, H.E.; Loft, S. A sucrose-rich diet induces mutations in the rat colon. Cancer Res. 2002, 62, 4339-4345.

69. Bufill, J.A. Colorectal cancer: evidence for distinct genetic categories based on proximal or distal tumor location. Ann. Intern. Med. 1990, 113, 779-788.

70. Lacopetta, B. Are there two sides to colorectal cancer? Int. J. Cancer 2002, 101, 403-408.

71. Lasson, S.C.; Bergkvist, L.; Wolk, A. High-fat dairy food and conjugated lioleic acid intakes in relation to colorectal cancer incidence in the Swedish Mammography Cohort. Am. J. Clin. Nutr. 2005, 82, 894-900.

72. Lindblom, A. Different mechanisms in the tumorigenesis of proximal and distal colon cancers. Curr. Opin. Oncol. 2001, 13, 63-69. 
73. Copeland, K.T.; Checkoway, H.; McMichale, A.J.; Holbrook, R.H. Bias due to misclassification in the estimate of relative risk. Am. J. Epidemiol. 1977, 105, 488-495.

74. D'Avanzo, B.; La Vecchia, C.; Katsouyanni, K.; Negri, E.; Trichopoulos, D. An assessment and reproducibility of food frequency data provided by hospital controls. Eur. J. Cancer Prev. 1997, 6, 288-293.

75. Wei, E.K.; Giovannucci, E.; Wu, K.; Rosner, B.; Fuchs, C.S.; Willett, W.C.; Colditz, G.A. Comparison of risk factors for colon and rectal cancer. Int. J. Cancer. 2004, 108, 433-442.

76. Fernandez, E.; Gallus, S.; La Vecchia, C.; Talamini, R.; Negri, E.; Franceschi, S. Family history and environmental risk factors for colon cancer. Cancer Epidemiol. Biomarkers Prev. 2004, 13, $658-661$.

Appendix 1. Quartile Cut-points for Fats, Protein and Carbohydrates Among Controls, NECSS Study, Canada, 1994-1997.

\begin{tabular}{lllll}
\hline \multirow{2}{*}{ Nutrients $(\mathrm{g} / \mathrm{wk})$} & \multicolumn{4}{c}{ Quartiles } \\
\cline { 2 - 5 } & \multicolumn{1}{c}{$\mathrm{I}(\mathrm{low})$} & \multicolumn{1}{c}{ II } & \multicolumn{1}{c}{ III } & IV (high) \\
\hline Total proteins & $\leq 356.47$ & $356.48-456.82$ & $456.83-575.25$ & $\geq 575.26$ \\
Total fats & $\leq 313.77$ & $313.78-422.16$ & $422.17-543.23$ & $\geq 543.24$ \\
Saturated fat & $\leq 115.77$ & $115.78-157.81$ & $157.82-205.93$ & $\geq 205.94$ \\
Monounsaturated fat & $\leq 109.48$ & $109.49-148.55$ & $148.56-194.37$ & $\geq 194.38$ \\
Polyunsaturated fat & $\leq 55.59$ & $55.60-74.56$ & $74.57-96.89$ & $\geq 96.90$ \\
Trans-fat & $\leq 6.86$ & $6.87-10.93$ & $10.94-19.07$ & $\geq 19.08$ \\
Cholesterol (mg/wk) & $\leq 966.26$ & $926.27-1412.75$ & $1412.76-1880.27$ & $\geq 1880.28$ \\
Total carbohydrates & 1406.49 & $1406.50-1790.47$ & $1790.48-2253.18$ & $\geq 2253.19$ \\
Sucrose & $\leq 150.76$ & $150.77-214.93$ & $214.94-283.79$ & $\geq 283.80$ \\
Lactose & $\leq 33.02$ & $33.03-93.94$ & $93.95-196.50$ & $\geq 196.51$ \\
Maltose & $\leq 7.56$ & $7.57-10.52$ & $10.53-14.41$ & $\geq 14.42$ \\
Glucose & $\leq 86.46$ & $86.47-123.40$ & $123.41-176.90$ & $\geq 176.91$ \\
Fructose & $\leq 90.88$ & $90.89-133.97$ & $133.98-194.10$ & $\geq 194.11$ \\
Galactose & $\leq 0.47$ & $0.48-0.75$ & $0.76-1.11$ & $\geq 1.12$ \\
\hline
\end{tabular}

(C) 2010 by the authors; licensee Molecular Diversity Preservation International, Basel, Switzerland. This article is an open-access article distributed under the terms and conditions of the Creative Commons Attribution license (http://creativecommons.org/licenses/by/3.0/). 